\title{
TARBAW
}

Volume 3 No.2, Juli-Desember 2018

p-ISSN : 2527-4082, e-ISSN : 2622-920X

\section{Rasionalisme Descartes dan Implikasinya Terhadap Pemikiran Pembaharuan Islam Muhammad Abduh}

Descartes's rationalism and its implications for the Islamic Renewal Thought of Muhammad Abduh

\section{Mursyid Fikri}

Mursyidfikri4@gmail.com | Universitas Islam Negeri Walisongo Semarang

\begin{abstract}
Abstrak
Peneitian ini bertujuan mengupas tentang paham rasionalisme yang dicetuskan Rene Descartes dan Implikasinya terhadap Pemikiran Pebaharuan Islam Muhammad Abduh. Rasionalisme Rene Descartes merupakan paham yang muncul ditengah kungkungan gereja Kristiani yang dikenal dengan masa skolastik. Paham ini lebih menekankan pada penggunaan akal (rasio) untuk memperoleh sebuah pengetahuan. Tentunya sebagai hasil filsafat, paham rasionalisme sangat berperan penting pada perkembangan ilmu-ilmu pengetahuan lain. Metode yang digunakan dalam penelitian ini adalah metode deskriptif kualitatif, Penulis mencoba mengaitkan dan menampilkan Implikasi antara pemikiran Rasionalisme descartes dan pemikiran pembaharuan dalam islam. Adapun hasil penelitian ini penulis melihat adanya benang merah antara dasar rasionalisme descartes dan pemikiran muhammad abduh bahwa keduanya menjadikan akal sebagai alat untuk melakukan penalaran terhadap suatu kebenaran.
\end{abstract}

Kata kunci : Rasionalisme Descartes, Implikasinya, Pemikiran Pembaharuan Muhammad Abduh 


\begin{abstract}
Absract
This study aims to explore the understanding of rationalism triggered by Rene Descartes and its implications for Islamic Reformation Muhammad Abduh. Rene's Reneisme Descartes is an understanding that emerged amidst the confines of the Christian church known as the scholastic period. This emphasis is more on the use of reason (ratio) to gain a knowledge. Certainly as a result of philosophy, the notion of rationalism is very important role in the development of other sciences. The method used in this research is descriptive qualitative method, the author tries to link and display the implication between Rationalism thinking descartes and thinking of renewal in Islam. The results of this study the authors see the existence of a common thread between the foundations of descartes rationalism and thought muhammad abduh that both make sense as a tool to make reasoning against a truth.
\end{abstract}

\title{
Keywords: Rationalism Descartes, Implication, Thinking Renewal Muhammad Abduh
}

\section{PENDAHULUAN}

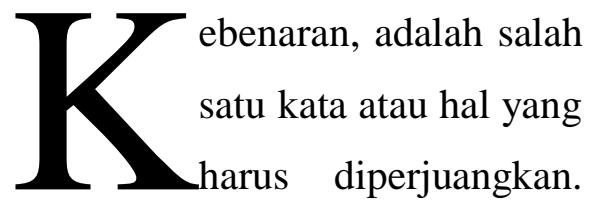

Untuk mencapai suatu kebenaran itu diperlukan berbagai macam cara berfikir maupun pembuktian. Selama ini cara yang mendominasi untuk pencapaian kebenaran adalah dengan kemampuan indera. Apa yang bisa diinderakan maka itu telah dianggap benar. Indera dijaidkan sebagai pangkal kebenaran. Akan tetapi sejak kemunculan seorang filosof beraliran rasionalisme, yaitu Rene Descartes yang sangat bertolak belakang dalam pencapaian kebenaran. Descartes menyatakan bahwa kebenaran itu dapat dicapai dengan berfikir yang bermula dari keraguan akan suatu pengetahuan. Di sinilah keberadaan akal didewakan.

Rasionalisme dipelopori oleh Rene Descartes (1596 - 1650) yang disebut sebagai bapak filsafat modern. Ia ahli dalam ilmu alam, ilmu hukum dan ilmu kedokteran. Ia menyatakan bahwa ilmu pengetahuan harus satu, tanpa bandingannya, harus disusun oleh satu orang sebagai bangunan yang berdiri sendiri menurut suatu metode yang umum.

Rene Descartes yang mendirikan aliran rasionalisme berpendapat bahwa sumber pengetahuan yang dapat dipercaya adalah akal. Hanya pengetahuan yang diperoleh lewat akallah yang memenuhi syarat yang dituntut oleh semua pengetahuan yang ilmiah. Dengan akal dapat diperoleh kebenaran dengan metode deduktif, seperti yang dicontohkan dalam ilmu pasti. (Asmoro Achmadi, 1994)

Senada dengan hal itu dalam gerakan pemikiran islam bermunculan berbagai gerakan yang disebut dengan gerakan pembaharuan islam yang dikenal dengan istilah tajdid. Di samping kata 
tajdid, ada istilah lain dalam kosa kata Islam tentang kebangkitan atau pembaruan, yaitu kata islah . Kata tajdid biasa diterjemahkan sebagai "pembaharuan", dan islah sebagai "perubahan". Kedua kata tersebut secara bersama-sama mencerminkan suatu tradisi yang berlanjut, yaitu suatu upaya menghidupkan kembali keimanan Islam beserta praktek-prakteknya dalam komunitas kaum muslimin.( John O. Voll, 1987).

Salah satu ciri pemikiran teologi modern adalah rasional. Banyak tokoh Islam yang mencoba melakukan pemikiran itu di antaranya adalah Muhammad Abduh. Beliau adalah seorang tokoh salaf yang menghargai kekuatan akal dan tetap memegang teksteks agama, meskipun ia tidak menghambakan diri pada teks-teks agama tersebut

Oleh sebab itu penulis mencoba menarik benang merah antara filsafat pemikiran rasionalisme descartes dengan makna dan goal dari gerakan pembaharuan dalam islam.

\section{METODE PENELITIAN}

Metode yang digunakan dalam penelitian ini adalah metode deskriptif kualitatif. Penelitian deskriptif merupakan penelitian yang bertujuan menggambarkan Implikasi antara pemikiran rene descartes dan pemikiran pembaharuan islam Muhammad Abduh . Sedangkan sumbernya diambil dari beberapa buku-buku ilmiah yang diterbitkan dengan maksud dijadikan sumber referensi Adapun Tekhnik pengumpulan data dalam penelitian ini ialah Studi Kepustakaan, Wawancara dan Observasi.

\section{PEMBAHASAN}

\section{A. BIOGRAFI TOKOH}

\section{Biografi Rene Descartes}

Rene Descartes lahir di La Haye, Perancis 31 Maret 1959. Descartes adalah seorang filsusuf berkebangsaan Perancis dan beragama katholik sekaligus penganut bid'ah Galileo yang pada waktu itu masih ditentang oleh tokoh-tokoh gereja.(Anggriani) . Descartes juga dikenal sebagai Renatus Cartesius. Dia merupakan seorang filsuf dan matematikawan Perancis. Karyanya yang terpenting adalah Discours de la method (1637) dan Meditationes de prima Philosophia (1641). Rene Descartes sering disebut sebagai "Bapak Filsafat Modern", menurut Bertnand Russel gelar itu diberikan kepada Descartes karena dialah orang pertama pada zaman modern yang membangun filsafat yang berdiri di 
atas keyakinan diri sendiri yang dihasilkan oleh pengetahuan rasional.

Dia sekolah di Universitas Jesuites di La Fleche dari tahun 1604-1612 M, yang tampaknya telah memberikannya dasar-dasar matematika modern, jauh lebih baik daripada yang bisa diperolehnya di kebanyakan universitas pada saat itu. Pada tahun 1612, dia pergi ke Paris, namun kehidupan di sana membuatnya bosan, dan kemudian dia mengasingkan diri di daerah terpencil di Fauborg St. Germain untuk menekuni Geometri. Namun demikian, temantemannya menemukannya, maka untuk lebih menyembunyikan diri, dia mendaftar sebagai tentara Belanda pada tahun 1617.

Tahun 1621, Descartes berhenti dari medan perang dan setelah berkelana ke Italia, lalu ia menetap di Paris (1625). Tiga tahun kemudian, ia kembali masuk tentara, tetapi tidak lama ia keluar lagi dan akhirnya memutuskan untuk hidup di negeri Belanda. Di sinilah, ia menetap selama 20 tahun (1629-1649) dalam iklim kebebasan berpikir. Di negeri inilah, ia dengan leluasa menyusun karya-karyanya di bidang ilmu dan filsafat. Meskipun Descartes tidak pernah menikah, tetapi dia mempunyai seorang anak perempuan kandung yang meninggal pada usia lima tahun, peristiwa ini menurutnya merupakan satu kesedihan paling dalam selama hidupnya.(Russell, 2007)

Descartes menghabiskan masa hidupnya di Swedia tatkala ia memenuhi undangan Ratu Christine yang menginginkan pelajaran-pelajaran darinya. Pelajaran-pelajaran yang diharuskan diajarkan setiap jam lima pagi menyebabkan Descartes jatuh sakit, yang menjemput ajalnya pada 11 Februari 1650 di usia 54 tahun, sebelum ia sempat menikah. Jenazahnya kemudian dipindahkan ke Prancis pada 1667, dan tengkoraknya disimpan di Museum d'Historie Naturelle, Paris.(Zubaedi, 2007)

Selain mencurahkan perhatiannya dalam bidang filsafat, Descartes juga dikenal sebagai seorang Polymath, yaitu seorang yang mempunyai perhatian luas dalam bidang ilmu pengetahuan, khususnya dalam ilmu pasti. Sumbangannya yang besar dalam dunia ilmu adalah keberhasilannya menemukan ilmu ukur koordinator (coordinatgeometri).

Karya-karya Descartes cukup banyak. Beberapa karyanya, antara lain adalah: Discours de la Methode (1637) yang berarti uraian tentang metode yang isinya melukiskan perkembangan intelektualnya. Di dalam karyanya inilah, 
ia menyatakan ketidakpuasannya atas filsafat dan ilmu pengetahuan yang menjadi bahan penyelidikannya. Dalam bidang ilmiah, tidak ada sesuatu pun yang dianggap pasti. Semuanya dapat dipersoalkan dan pada kenyataannya memang dipersoalkan juga. Satu-satunya pengecualian adalah ilmu pasti. Demikian menurut Descartes. (Abdul Hakim, 2008)

\section{Biografi Muhammad Abduh}

Muhammad Abduh adalah seorang pemikir, teolog, dan pembaru dalam Islam di Mesir yang hidup pada akhir abad ke-19 dan awal abad ke-20. Kapan dan di mana Muhammad Abduh lahir tidak diketahui secara pasti, karena ibu bapaknya adalah orang desa biasa yang tidak mementingkan tanggal dan tempat lahir anak-anaknya. Tahun $1849 \mathrm{M}$ / $1265 \mathrm{H}$ adalah tahun yang umum dipakai sebagai tanggal lahirnya.(Nasution, 1987) Ia lahir di suatu desa di Mesir Hilir, diperkirakan di Mahallat Nasr. Bapak Muhammad Abduh bernama Abduh Hasan Khairullah, berasal dari Turki yang telah lama tinggal di Mesir. Ibunya berasal dari bangsa Arab yang silsilahnya meningkat sampai ke suku bangsa Umar ibn al-Khattab.

Muhammad Abduh di suruh belajar menulis dan membaca setelah mahir, ia diserahkan kepada satu guru untuk dilatih menghafal Al-Qur'an. Hanya dalam masa dua tahun, ia dapat menghafal Al-Qur'an secara keseluruhan. Kemudian, ia dikirim ke Tanta untuk belajar agama di Masjid Syekh Ahmad di tahun 1862, setelah dua tahun belajar, ia merasa tidak mengerti apa-apa karena di sana menggunakan metode menghafal. Ia akhirnya lari meninggalkan pelajaran dan pulang ke kampungnya dan berniat bekerja sebagai petani. Tahun 1865 (usia 16 tahun) iapun menikah. Baru empat puluh hari menikah, ia dipaksa untuk kembali belajar ke Tanta. Iapun pergi, tapi bukan ke Tanta. Dia bersembunyi di rumah salah seorang pamannya, Syekh Darwisy Khadr. Syekh Darwisy tahu keengganan Abduh untuk belajar, maka ia selalu membujuk pemuda itu supaya membaca buku bersama-sama. Setelah itu, Abduhpun berubah sikapnya sehingga kemudian ia pergi ke Tanta untuk meneruskan pelajarannya.

Selepas dari Tanta, ia melanjutkan studi di al-Azhar dari tahun 1869-1877 dan ia mendapat predikat "alim". Di sanalah ia bertemu dengan Jamaluddin alAfghani yang kemudian menjadi muridnya yang paling setia. Dari alAfghani yang kemudian belajar logika. Filsafat, teologi dan tasawuf. 
Tahun 1879, Abduh dibuang keluar kota Kairo karena dituduh turut berperan dalam mengadakan gerakan Khadowi Taufik. Hanya setahun ia dibuang, tahun 1880 ia boleh kembali dan kemudian diangkat menjadi redaktur surat kabar resmi pemerintah Mesir “ ع "يرصما"

Di akhir tahun 1882, Ia lagi-lagi dibuang. Tapi kali ini dibuang ke luar negeri dan ia memutuskan pergi ke Beirut. Alasan pembuangan ini adalah keterlibatan Abduh dalam revolusi (pemberontakan) Urabi Pasya. Baru setahun di Beirut, dia diundang al-Afghani supaya datang ke Paris guna membentuk gerakan al-Urwah al-Wusqa. Tujuan gerakan ini adalah membangkitkan semangat perjuangan umat Islam untuk menentang ekspansi Eropa di dunia Islam. Terbitlah majalah al-Urwah al-Wusqa. Ide pemikiran berasal dari al-Afghani, sedangkan tulisan yang mengungkapkan pemikiran itu dilakukan oleh Abduh. Majalah tersebut hanya bertahan delapan bulan dengan 18 kali terbit. Setelah itu, ia berpisah dengan gurunya. Gurunya menuju Persia, ada juga yang mengatakan ke Rusia. Sedangkan ia sendiri kembali ke Beirut pada tahun 1885 M. di Kota ini, ia pusatkan perhatiannya pada ilmu dan pendidikan. Ia mengajar di Madrasah
Sultaniah dan di rumahnya sendiri. Pelajaran tauhid yang diberikannya di Madrasah Sultaniah tersebut menjadi dasar dari Risalah al-Tauhid- nya.

Sekembalinya dari pembuangan, di akhir tahun 1888, ia mulai aktivitasnya. Karirnya dimulai dari menjadi hakim Pengadilan Negeri kemudian menjadi penasehat Mahkamah Tinggi. Di sela-sela kesibukannya sebagai hakim ia berusaha memperbaiki pendidikan di al-Azhar. Ia ingin membawa ilmu-ilmu modern yang sedang berkembang di Eropa ke al-Azhar. Usahanya tidak berjalan mulus bahkan usahanya kandas. Banyak tantangan dari para ulama' yang berpegang pada tradisi lama. Tahun 1899, ia diangkat menjadi Mufti Mesir, suatu jabatan resmi penting di Mesir dalam menafsirkan hukum syari'at untuk seluruh Mesir. Di tahun yang sama, ia juga diangkat menjadi anggota majlis syura.

Begitu pula Abduh tidak bisa menjalankan ibadah haji hingga akhir hayatnya karena faktor politik. Akhirnya, pada 11 Juli 1905, Abduh dipanggil ke hadirat Allah setelah agak lama ia menderita kanker hati. di usia yang belum begitu tua yaitu sekitar 56 tahun.

Abduh meninggalkan banyak karya tulis, sebagian besar berupa artikelartikel di surat kabar dan majallah. Yang 
berupa buku antara lain Durus min AlQur'an (Berbagai pelajaran dari AlQur'an), Risalah al-Tauhid (Risalah Tauhid), Hasyiyah 'Ala Syarh al-Dawani li al-'Aqaid al-'Adudiyah (Komentar terhadap Penjelasan al-Dawani terhadap Akidah-akidah yang Meleset), al-Islam wa al-Nasraniyah (Islam dan Nasrani bersama Ilmu-ilmu Peradaban). Tafsir Al-Qur'an al-Karim juz 'Amma (Tafsir AlQur'an juz Amma), dan Tafsir al-Manar yang diselesaikan oleh muridnya Syekh Muhammad Rasyid Ridha.

\section{Konstruksi Epistimologi Descartes}

1. Sumber dan hakikat pengetahuan Sebagai seorang tokoh rasionalisme yang sering disebut-sebut sebagai bapak filsafat modern, Descartes memiliki fondasi dasar ajaran filsafat yang sangat populer dan tidak tergoyahkan, yakni tentang ajaran yang menegaskan bahwa kebenaran tertinggi berada pada akal budi manusia. Menurut Descartes, rasio merupakan sumber pengetahuan. Hanya rasio sajalah yang dapat membawa orang pada kebenaran. Yang benar hanyalah tindakan akal yang terang benderang yang disebutnya Ideas Claires el Distinctes (pikiran yang terang benderang dan terpilah-pilah).(Abdul Hakim )
Untuk itulah, Descartes menekankan agar tidak mempercayai segala sesuatu di luar rasio manusia, karena kesaksian apapun yang bersumber dari luar rasio manusia adalah tidak pasti dan tidak dapat dipercayai. Kebenaran harus dicari dan didasarkan dengan menggunakan kriteria "clearly and distinctly". Selain itu, ia juga mengemukakan tentang adanya tiga ideide bawaan (innate ideas). yaitu:

a. Idea pemikiran: ide yang memungkinkan diri saya sebagai makhluk yang berpikir (pemikiran adalah hakikat saya).

b. Idea Allah sebagai wujud sempurna, karena saya mempunyai idea yang sempurna, maka pasti ada sesuatu yang sempurna itu. Wujud yang sempurna itu adalah Allah.

c. Idea keluasan: yang memungkinkan saya (kita) mengerti materi (benda-benda, objek-objek) sebagai keluasan, sebagaimana hal itu dapat dipelajari secara kuantitatif (ilmu ukur/matematika).

Di sisi lain, untuk membuktikan kepada kita bahwa kita tidak bisa begitu saja percaya terhadap indra kita. Descartes menunjukkan pengalaman mimpi yang tampak sangat nyata, bahkan 
ketika kita melakukan sesuatu yang tidak dapat kita lakukan ketika dalam keadaan sadar (seperti terbang), hal itu nampak bahwa kita sungguh-sungguh dapat melakukannya. Karena itulah, tidak ada sesuatu apapun yang dapat meyakinkan kita bahwa kita tidak sedang bermimpi saat ini. Dan jika kita tidak bisa yakin bahwa kita saat ini tidak sedang bermimpi, kita tidak bisa memperoleh pengetahuan melalui penggunaan indra kita. (Theodore,th 400)

2. Metode Keraguan Rene Descartes (The Method of Cartesian Doubt)

Berawal dari keinginan untuk menemukan metode yang ampuh dalam mencari kepastian hakiki suatu pengetahuan dan memastikan bahwa sesuatu yang ada itu benar-benar ada dan bukan hanya khayalan semata. Descartes membangun suatu fondasi dasar yang ia sebut sebagai Metode Keraguan. Suatu metode yang dia awali dengan upaya menyangsikan segala sesuatu. Sebagaimana yang ditulis oleh Sakban Rosidi.

"Cartesian Method starts from doubting everything. "De Omnibus dubitandum". Thinking is but to doubt everything. On the principles of human knowledge, Descartes asserted: First, that in order to seek the truth, it is necessary once in the course of our life to doubt. As far as possible, of all things. Second, that we ought also consider as false all that is doubtful." Sakba, 2002) .

Descartes bertolak dari kenyataan di mana kita (manusia) sering tertipu oleh pengamatan, seperti Argumen Plato, yang menyatakan bahwa tongkat yang terdapat di kolam yang bergelombang kelihatan bengkok, jalan lurus di ujungnya kelihatan bertemu, dan seterusnya. Descartes terus meragukan segala hal, meski sekecil apapun. Hal ini sebagaimana yang diungkapkan Descartes :

"... I suppose that everything I see is false. I believe that none of what my deceitful memory represents ever existed. I have no sense whatever. Body, shape, extension, movement, and place are all chimeras. What then will be true? Perhaps just the single fact that nothing is certain.".( Rene Descartes, 1993)

Keraguan Descartes tampaknya bisa dipahami, karena bisa saja ada sesuatu (oleh Descartes disebut dengan "si jenius atau setan jahat") yang bisa menipu atau memalsu penalaran, sehingga sesuatu yang salah akan tampak sebagai kebenaran. Descartes mengalami kesulitan untuk membuktikan dan mengetahui adanya dunia luar dengan bertolak dari gagasan "cogito ergo sum" nya. Dan untuk membuktikan bahwa ia tidak tertipu tentang adanya dunia luar, 
maka ia bertolak dari adanya eksistensi Tuhan yang menjamin, karena menurutnya hanya Tuhan yang dapat menjamin bahwa:

a. ide-ide kita yang jelas dan terpilah memang benar,

b. kita tidak tertipu oleh setan jahat. Descartes menggunakan argumen ontologis tentang adanya Tuhan dari Anselmus sebagai dasar metodenya. Allah sebagai penyebab ide yang sempurna dalam pemikiran kita. Begitu Descartes membuktikan adanya eksistensi Tuhan, maka Descartes merasa memiliki dasar untuk mengakui; adanya tubuh kita yang berbeda dari rasio. bahwa ide kita mengenai dunia luar adalah benar. Setelah meragukan segala hal, bahkan keberadaannya sendiri, maka ada sesuatu yang tidak dapat diragukan keberadaannya (saya) yang sedang ragu itu.

Adanya saya yang ragu itu secara langsung membuktikan adanya saya yang berpikir, (cogito ergo sum; saya berpikir, maka saya ada). "Aku berpikir" merupakan kebenaran filsafat pertama (primum philosophicum). Tidak peduli betapa pun asam keraguan menggerogoti, keraguan ini tidak dapat menelan habis dasar dari keberadaannya sendiri; yaitu eksistensi dari orang yang meragukan.
Descartes menempatkan peran rasio, intuisi dan penalaran deduktif dalam mencapai yang pasti.

Descartes mengajukan beberapa prinsip metodologis yang dapat menjadi landasan dalam berpikir :

a. Tidak menerima apapun sebagai hal yang benar, kecuali kalau diyakini sendiri bahwa itu memang benar.

b. Memilah-milah masalah menjadi bagian-bagian terkecil untuk mempermudah penyelesaian.

c. Berpikir runtut dengan mulai dari hal yang sederhana, sedikit demi sedikit untuk sampai ke hal yang paling rumit.

d. Perincian yang lengkap dan pemeriksaan menyeluruh diperlukan, supaya tidak ada yang terlupakan.

\section{Teori Kebenaran Pengetahuan}

Teori kebenaran pengetahuan yang dianut oleh Descartes dan para kaum rasionalis adalah teori konsistensi atau koherensi (the consistence theory of the truth, the accordance theory of truth). Teori konsistensi atau koherensi adalah suatu proposisi atau makna pernyataan dari suatu pengetahuan bernilai benar bila proposisi itu mempunyai hubungan 
dengan ide-ide dari proposisi yang terdahulu bernilai benar.

Sebagai contoh, kita sebagai bangsa Indonesia pasti memiliki pengetahuan bahwa Indonesia diproklamirkan kemerdekaannya pada tanggal 17 Agustus 1945 bertepatan dengan hari Jumat tanggal 17 Ramadhan. Jika seseorang hendak membuktikannya, tidak dapat langsung melalui kenyataan dalam objektivanya, karena kenyataan hal tersebut telah berlangsung 65 tahun yang lalu. Untuk membuktikannya, maka harus melalui ungkapan-ungkapan tentang fakta itu, yaitu melalui sejarah atau dapat diafirmasikan kepada orang-orang yang mengalami dan mengetahui kejadian itu.

Dengan demikian, kebenaran dari pengetahuan itu dapat diuji melalui kejadian-kejadian sejarah, atau juga pembuktian proposisi itu melalui hubungan logis jika pernyataan yang hendak dibuktikan kebenarannya berkaitan dengan pernyataan-pernyataan logis atau matematis.

\section{Pemikiran Dan Ide Pembaharuan Muhammad Abduh}

Dipandang dalam aspek pembaruan teologi dan hukum, maka Muhammad Abduh dapat digolongkan sebagai seorang pembaharu pada zamannya. Pemikirannya muncul atas situasi dan tuntutan sosial yang mengharuskannya melakukan pembaharuan. Oleh sebab itulah ia digolongkan sebagai kaum modernis, yakni orang yang paling cepat tanggap merespon perkembangan yang terjadi dan sekaligus paling cepat diresponi oleh masyarakat sekitarnya.

Kalau dicermati secara seksama, sesungguhnya gagasan pembaruan Abduh bertumpu pada tiga hal berikut; (1) Pembebasan pemikiran dari belenggu taqlid sehingga akal tidak tunduk pada otoritas manapun. (2) Purifikasi (Gerakan Pemurnian ajaran Islam). (3) Penempatan agama sejajar dengan perkembangan ilmu pengetahuan, atau dengan kata lain, menjadikan sains sebagai partner agama. Berikut akan diuraikan secara lebih mendalam pokok-pokok pemikiran Muhammad Abduh tersebut :

\section{a. Pembebasan pemikiran dari belenggu taqlid \\ Dalam masalah ini Abduh tidak menghendaki adanya taqlid, dan mengobarkan seruan agar pintu ijtihad selalu terbuka. Bahkan dengan bersemangat ia menyampaikan bahwa tidak ada pertentangan antara ilmu dan agama, al-Qur'an bukan saja sesuai dengan ilmu pengetahuan tapi}


juga mendorong semangat umat Islam untuk mengembangkannya.

Ide Muhammad Abduh tersebut ternyata mendapatkan sambutan yang cukup luas dan hampir menyebar ke seluruh dunia Islam. seruannya untuk anti taqlid, memang mencerminkan kenyataan umat Islam yang tengah mengalami kejumudan berpikir. Sikap demikian pada gilirannya mengalami sikap antipati terhadap sains modern, dan merupakan sikap yang harus dihapuskan menurut Abduh.

Dalam beberapa hal, pemikiran Abduh memiliki garis penghubung dengan Muhammad bin Abdul Wahab, yakni ingin mengembalikan pemahaman agama sebagai ulama salaf. Kendatipun demikian, karena sikapnya yang sangat positif terhadap sains, Abduh berpendapat bahwa ajaran-ajaran Islam perlu diberi interpretasi baru, dan pintu ijtihad harus dibuka selebar-lebarnya. Ijtihad menurut pendapatnya bukan hanya boleh, malahan penting dan perlu diadakan. Tetapi yang dimaksudkannya bukan tiap-tiap orang boleh melakukan ijtihad. Hanya orang yang memenuhi syaratsyarat yang diperlukan yang boleh melakukan ijtihad. Yang tak memenuhi syarat, harus mengikuti pendapat mujtahid yang ia setujui fahamnya. Ijtihad dilakukan langsung pada al-Qur'an dan Hadis sebagai sumber yang asli dari ajaran-ajaran Islam.

Dengan demikian, taqlid kepada ulama lama tak perlu dipertahankan bahkan mesti diperangi karena taqlid inilah yang membuat umat Islam berada dalam kemunduran dan tak dapat maju. Pendapat tentang pemberantasan taqlid dan pembukaan pintu ijtihad didasarkan atau kepercayaannya pada kekuatan akal. Menurut abduh, al-Qur'an berbicara bukan semata kepada hati manusia, tetapi juga kepada akalnya.

Kepercayaan pada kekuatan akal membawa Muhammad Abduh selanjutnya kepada faham bahwa manusia mempunyai kebebasan dalam kemauan dan perbuatan (free will and free act atau qadariyah), dengan faham tersebut, maka manusia akan bebas mewujudkan perbuatannya dengan kemauan dan usahanya sendiri, dan tentunya dengan tidak melupakan bahwa diatasnya masih ada kekuasaan yang lebih tinggi. 


\section{b. Purifikasi (Gerakan pemurnian ajaran Islam)}

Abduh berupaya untuk
memurnikan ajaran Islam dengan kembali pada al-Qur'an dan Hadis Nabi, hal ini terkait dengan banyaknya fenomena bid'ah dan khurafat. Menurutnya, kaum Muslim tidak perlu mempercayai adanya karamah yang dimiliki wali atau kemampuan mereka sebagai perantara atau wasilah kepada Allah. Syirik harus dihindari karena tidak sesuai dengan akidah Islam.

Lebih lanjut, Abduh juga menekankan bahwa mentauhidkan Allah merupakan pangkal dari segala keimanan yang lainnya. Dalam hal ini seruan mentauhidkan itu tidak bersandar pada dalil apapun kecuali nash qath "iy yang dipadukan dengan pemakaian rasio yang benar. Inilah salah satu prinsip penting yang menjadi pedoman Abduh. Abduh telah mencoba menempatkan posisi tauhid pada posisinya yang lurus dengan mengesampingkan bentukbentuk pemahaman keagamaan yang mempunyai kekuatan sumber (otoritas).

Dalam pandangan Abduh, bahwa masuknya berbagai macam bid'ah ke dalam Islamlah yang membuat Islam lupa akan ajaran-ajaran Islam yang sebenarnya. Bid'ah-bid'ah itulah yang mewujudkan masyarakat Islam yang jauh menyeleweng dari masyarakat Islam yang sebenarnya. Untuk menolong umat Islam, fahamfaham asing lagi salah itu harus dikeluarkan dari tubuh Islam. Umat harus kembali ke ajaran-ajaran Islam yang semula, ajaran-ajaran sebagaimana terdapat di zaman salaf, yaitu di zaman sahabat dan ulamaulama' besar.(Harun, 1996)

Perlu ditegaskan juga bahwa bagi Muhammad Abduh tidak cukup hanya kembali kepada ajaran-ajaran asli itu, karena zaman dan suasana umat Islam sekarang telah jauh berubah dari zaman dan suasana umat Islam zaman klasik, ajaran-ajaran asli itu perlu disesuaikan dengan keadaan modern sekarang.

\section{c. Pembaharuan dalam pendidikan}

\section{Islam}

Program pembaharuan Abduh juga berfokus pada pembaharuan pendidikan Islam dan perumusan ajaran-ajaran Islam dalam pengertian, kalau tidak menurut pemikiran modern, setidak-tidaknya yang lebih bisa diterima oleh orang-orang 
modern. Tantangan pendidikan Islam terutama berkaitan dengan masalah orientasi pendidikan Islam, sumber daya manusia, anggaran pendidikan, kurikulum, informasi dan teknologi, globalisasi.

Dari pada perumusan abad pertengahan yang sudah ketinggalan zaman. Secara ideal kedua butir ini merupakan dua aspek dari kegiatan yang sama dan merupakan kelengkapan yang diperlukan untuk melaksanakan pemurnian Islam. Karena hanya dengan meningkatkan mutu pendidikan Islam dan mengemukakan kembali ajaranajaran dasar Islam dengan tegas dan jelas, pengaruh-pengaruh yang merusak, baik yang bersifat animistik maupun materialistik dapat dikeluarkan dan dilenyapkan.( Ihsan, 2015)

Dalam pandangan Abduh, konsep pendidikan yang dikemukakan oleh Jamaluddin dalam bukunya "Refutation of the Materialistik" (ArRaddu“ „alad Dahriyyin) begitu umum pengertian-pengertiannya, sehingga sedikit saja menunjukkan pemikirannya. Dilain pihak, penolakan Abduh terhadap idealisme revolusioner Jamaluddin Al-Afghani menjadikan Abduh untuk lebih memfokuskan tujuan utamanya untuk mengembangkan landasan pendidikan, terutama universitas alAzhar. Salah satu artikelnya yang dikirimkannya ke surat kabar Alahram pada tahun 1876, yang meskipun ketika itu dia masih dibawah pengaruh Jamaluddin alAfghani, ia menyatakan dengan tegas bahwa kewajiban belajar tidak hanya mengenai buku-buku klasik berbahasa Arab dan tentang ilmuilmu kalam dogmatik dalam rangka membela agama, tetapi juga berbagai sains modern serta sejarah dan agama eropa agar dapat mengetahui sebabsebab kemajuan bangsa-bangsa Barat.

Penegasan Abduh untuk memasukkan materi sains modern kedalam kurikulum al-Azhar juga dilandaskan pada kegelisahannya terhadap munculnya dua tipe pendidikan di Mesir pada waktu itu. Tipe pertama, sekolah-sekolah tradisional dengan al-Azhar sebagai lembaga pendidikan tertinggi, tipe kedua, sekolah-sekolah modern baik yang didirikan oleh pemerintah Mesir maupun oleh para missionaris asing. Pada waktu itu, sekolah-sekolah agama semata-mata mengajarkan 
ilmu agama belaka, dan mengabaikan ilmu-ilmu umum atau tidak mengajarkan ilmu-ilmu yang datang dari Barat. Sementara sekolahsekolah modern tampil dengan kurikulum yang memberikan ilmu pengetahuan Barat sepenuhnya, tanpa adanya upaya untuk memasukkan ilmu pengetahuan agama ke dalam kurikulumnya.( Gibb, 1993)

Selain itu, Abduh juga menghidupkan metode munazarah (discussion) dalam memahami pengetahuan yang sebelumnya banyak mengarah kepada taqlid semata terhadap pendapat ulamaulama tertentu yang dianggap mempunyai berpengaruh. $\mathrm{Hal}$ tersebut diubahnya dengan jalan pengembangan kebebasan intelektual di kalangan mahasiswa al-Azhar. Demikian juga halnya dengan sikap ilmiah, terutama dalam memahami sumber-sumber ilmu agama yang selama ini memiliki landasan yang tidak dapat diganggu gugat oleh pemikiran dan kemajuan zaman.

Dengan perbaikan-perbaikan serta pembaharuan yang dibawa oleh Muhammad Abduh ke dalam tubuh al-Azhar, beliau berharap agar universitas ini kelak akan menjadi pusat pembaharuan yang diinginkan dalam dunia Islam. Akan tetapi usahanya ini kandas karena mendapat tantangan dari kalangan ulama yang kuat berpegang pada tradisi lama serta teguh dalam mempertahankannya. Namun demikian, di al-Azhar tersebut Abduh meninggalkan kelompok orang-orang yang berpikir cerah, sekalipun hanya sedikit yang percaya pada prinsip-prinsip yang diletakkan oleh Abduh dan menerima pandangan-pandangannya, dan sekalipun juga mereka tidak mempunyai keberanian dan kegairahan seperti Muhammad Abduh.(Mukti Ali, 1995)

\section{B. Rasionalisme Descartes Dan}

\section{Implikasinya Terhadap Pemikiran} Pembaharuan Muhammad Abduh

Pengaruh Rasionalisme ala Descartes ini sangat didukung oleh AlQuran sebagai salah satu sumber ilmu pengetahuan dalam Islam disamping hadist. Al-Quran merupakan kitab suci yang sangat menghormati budaya rasionalitas ilmiah dan menolak segala bentuk khurafat (mitos). Akal (rasio) dalam Islam sangat memberikan kedudukan yang istimewa. Dengan akal, manusia dapat mencapai peradaban dan 
kebudayaan yang sangat tinggi dan dengan akal pula ia dapat mengemban tugas sebagai khalifah di muka bumi. Bahkan Allah sendiri seringkali memerintahkan manusia dalam Al-Quran untuk menggunakan akal, termasuk dalam menggunakan Al-Quran itu sendiri. Bahkan Allah sangat membenci orangorang yang tidak menggunakan akalnya sebagaimana disampaikan dalam Surat Yunus ayat 100. Selain itu, dalam beberapa ayat Al-Quran Allah juga memerintahkan kepada manusia untuk menggunakan akalnya untuk berfikir.

Dalam ilmu-ilmu keislaman, konsep rasionalisme dikenal dengan sebutan metode atau konstrksi pemikiran Burhani. Sistem Burhani adalah menggunakan prinsip-prinsip dasar logika (al-mantiq) yang meyakinkan, yang kemudian diteliti kesimpulankesimpulannya atau inferensi yang secara pasti lahir dari prinsip tersebut. Dalam konstruksi pemikiran Burhani, ia bersumber pada realitas atau al-Waqi baik realitas alam, sosial, humanitas atau keagamaan. Ilmu yang muncul dalam tradisi Burhani disebut sebagai al-'ilm al hushuli, yakni ilmu yang dikonsep, disusun dan disistematisasikan lewat premis-premis logika atau al mantiq, bukan melalui otoritas teks seperti konstruksi Bayani atau pengalaman langsung dalam konstruksi Irfani.

Lalu bagaimana keterkaitan rasionalisme Descartes dengan pemikiran Muhammad Abduh ? Dijelaskan Muhammad Abduh, salah satu tokoh filsafat muslim ternama, bahwa islam adalah agama yang rasional, agama yang sejalan dengan akal bahkan ajaran agama yang didasarkan atas akal. Semua ajaranajaran Islam baik tentang akidah, akhlak maupun tasawuf adalah ajaran yang sangat rasional dan dapat diakal.

Dari pandangan itu, Abduh sangat menolak taqlid dan menerima penafsiran (ta'wil) berdasarkan asal ketimbang menerima terjemahan literal mengenai sumber-sumber agama. Abduh melalui pandangannya itu mengajak umat Islam untuk melakukan ta'wil terhadap nashnash Al-Qur'an yang tidak bisa kita pahami. Ia juga menegaskan lewat bukubukunya agar memisahkan pemahaman tentang eksistensi dan karakter ajaran agama yang seutuhnya dengan hasil pemikiran orang-orang yang hanya mengaku dirinya sebagai agamawan.

Oleh sebab itu dari pemikiran Muhammad abduh dan Rasionalisme Descartes bisa di tarik benang merah yakni rasionalisme dan Pemikiran pemaharuan islam keduanya menjadikan 
akal sebagai alat untuk melakukan penalaran terhadap suatu kebenaran.

\section{PENUTUP}

1. Descartes memiliki fondasi dasar ajaran filsafat yang sangat populer dan tidak tergoyahkan, yakni tentang ajaran yang menegaskan bahwa kebenaran tertinggi berada pada akal budi manusia. Menurut Descartes, rasio merupakan sumber pengetahuan. Hanya rasio sajalah yang dapat membawa orang pada kebenaran. Yang benar hanyalah tindakan akal yang terang benderang yang disebutnya Ideas Claires el Distinctes (pikiran yang terang benderang dan terpilah-pilah).

2. Pembaharuan pemikiran Islam Muhammad Abduh bertumpuk pada tiga hal yakni pembebasan pemikiran ummat islam terhadap kebiasaan taqlid sehingga akal tidak tunduk pada otoritas manapun, Purifikasi (Gerakan Pemurnian ajaran Islam). Penempatan agama sejajar dengan perkembangan ilmu pengetahuan, atau dengan kata lain, menjadikan sains sebagai partner agama.

3. Implikasi antara Rasionalisme Descartes dengan pemikiran pembahruan Muhammad abduh bisa di tarik benang merah yakni rasionalisme dan Pemikiran pemaharuan islam keduanya menjadikan akal sebagai alat untuk melakukan penalaran terhadap suatu kebenaran.

\section{DAFTAR PUSTAKA}

Abbas Nurlaela, 2014, Muhammad Abduh :Konsep Rasionalisme Dalam Islam. (Jurnal Dakwah Tabligh),

Achmadi Asmoro, 1994, Filsafat Umum, (Jakarta: PT. Raja Grafindo Persada,)

Aziz . Amir .Ahmad, 2009 Pembaruan Teologi..., (Yogyakarta: Teras).

Anggriani, S, 2018, "Tokoh Filsafat Modern Rene Descartes (cogito ergo sum)", http://www.academia.edu .

Asmuni. Yusran, 1998, Pengantar Studi Pemikiran...(.Jakarta: PT Raja Grafindo Persada).

Ali. Mukti, 1995, Alam Pikiran Islam Modern di Timur Tengah, (Jakarta: Djambatan)

Azizi, Amir. Ahmad. dan Mukti Sahal, 1992. Teologi Islam..., (Surabaya: Gitamedia Press)

Bawenga, 1983, Sebuah Studi Filsafat (Jakarta: Pradnya Paramita,).

Donohue. J. John dan John L. Esposito (ed), 1984, Islam dan Pembaharuan; Ensiklopedi 
masalah-masalah, terj. Machnun Husein, (Jakarta: Rajawali)

Dacholfany M. Ihsan, 2015, Reformasi Pendidikan Islam Dalam Menghadapi Era Globalisasi: Sebuah Tantangan dan Harapan, Akademika, (STAIN Metro, Vol. 20)

Dewan Redaksi Ensiklopedi Islam, 2001, Ensiklopedi Islam, juz 3, cet. 4, (Jakarta : PT. Ichtiar Baru Van Hoeve).

Fauzan dan Suwito (ed), 2003 Sejarah Pemikiran Para Tokoh Pendidikan, (Bandung: Angkasa,).

Gibb. H.A.R., 1993. Aliran-aliran Modern dalam Islam, terj. Machnun Husein, (Jakarta: PT Raja Grafindo Persada).

Gallagher Kenneth T., 1994, Epistemologi., terj. Hardono Hadi (Yogyakarta: Kanisius,).

Hakim Abdul Atang dan Beni Ahmad Saebani, 2008. Filsafat Umum; Dari Metologi sampai Teofilosofi . (Bandung: CV Pustaka Setia)

Russell Bertrand, 2007. Sejarah Filsafat Barat: Kaitannya Dengan Kondisi Sosio-Politik Zaman Kuno Hingga Sekarang , (Yogyakarta: Pustaka Pelajar).
Rosidi Sakban, 2002. The History of Modern Thought; A Brief but Critical Reminder (Malang: CISC)

Rakhmawanti, Erva Yuly Muhammad Abduh dan Gagasan Pembaharuan Islam, (Makalah tidak diterbitkan,)

Nasution, 1987, Muhammad Abduh dan teologi Rasional Mu'tazilah, cet.1, (Jakarta : UI Press)

Nasution, 1987, Pembaharuan dalam Islam Sejarah Pemikiran dan Gerakan, cet. 5, (Jakarta : Bulan Bintang).

Shihab M. Quraish, 1994, Studi Kritis Tafsir Al-Manar; Karya Muhammad Abduh dan M. Rasyid Ridha,(Bandung: Pustaka Hidayah).

Syihab M. Quraisy, 2007, Ensiklopedi alQur'an Kajian Kosa kata, cet. I, (Jakarta : Lentera Hati, 1428 H/)

Schick Theodore, Jr, Lewis Vaughn, Doing Philosophy; An Introduction Through.

Tim Dosen Filsafat Ilmu UGM, Filsafat Ilmu; Sebagai Dasar Pengembangan Ilmu Pengetahuan (Yogyakarta: Liberty, 2003), 80-81

Zubaedi dkk, 2007, Filsafat Barat; Dari Logika Baru Rene Descartes Hingga Revolusi Sains ala Thomas Khun, (Yogyakarta: Ar Ruzz Media,). 